\title{
Gender Domesticity Reinterpreted: Housework Division in Dual-Work Moroccan Families
}

\author{
Rostom Meryem, (PhD.) \\ Mohamed V University, Morocco
}

Doi:10.19044/esj.2018.v14n17p131 URL:http://dx.doi.org/10.19044/esj.2018.v14n17p131

\begin{abstract}
Research on the gendered division of household labour suggests that spouses' inequitable housework division is determined by economic, cultural and/ or pragmatic considerations. While these factors are partially supported by the literature on household labour division, results of this study further suggested that women perform more housework than their spouses out of choice and are not necessarily unhappy with their unbalanced share. The data for the study were drawn from in-depth semi-structured interviews administered to 30 Moroccan female primary school teachers. Building on Thompson's (1991) distributive justice framework, this paper focuses on examining women's underlying motivation for doing a far greater proportion of housework tasks than do their husbands in spite of working for pay. It also states the implications of such a deliberate choice.
\end{abstract}

Keywords: Housework division, fairness, gender roles, subjective factors, Morocco

\section{Introduction}

Over the last century, advanced capitalism has made remarkable changes in women's lives. They have entered the labour force massively and have joined men in social production. Therefore, the traditional nuclear family, composed of a homemaker wife and a breadwinner husband, is no longer the norm in all families today. In Morocco, the rate of female labour force participation is one of the highest in the Arab world (27,1\% in 2016) ${ }^{36}$, with an increasing number of female-headed households $(16,2 \%)$, and of wives as primary breadwinners ${ }^{37}$ in the absence of a good- paying or regular job for the husband. However, despite the shift from single-earner to dualincome family type, household labour arrangements have lagged behind the pace of change. In other words, though women's participation in paid labour

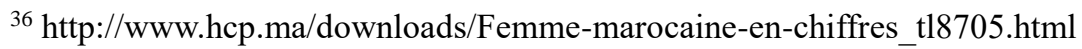

${ }^{37}$ Direction de la statistique, RGPH 2014 : https//rgph 2014.hcp.ma
} 
have begun to mirror those of men, their responsibilities at home are far greater than those of their husbands (Berk, 1985; Belarbi, 1991; Ferree 1991; Hochschild, 1989). In fact, research has suggested some puzzling findings. Though they generally perform more housework than their spouses, employed women often fail to report an inequitable division of tasks within the household. In this paper, we attempt to contribute to the understanding of the inequity of household labour division among dual-employed couples by examining factors that make women shoulder much of the responsibility for household labour though they also work outside for pay. We hypothesize, therefore, that this "second shift", as Hochschild (1989) refers to it, is likely to have negative consequences on women's well-being and thus on the quality of their life.

\section{Theoretical approaches to Household labour division}

Different explanations have been offered by social scientists to account for the paradoxical situation whereby women continue to perform the bulk of domestic tasks regardless of their commitments in the workplace. The relative resources approach, for instance, posits that resources such as income, educational attainment or occupational status each spouse is endowed with can serve as an implicit means to negotiate one's release from doing domestic chores (Bianchi, et al., 2000; Blood \& Wolf, 1960; Brines, 1994; Coverman, 1985; Kamo, 1988). The time availability theory, commonly referring to the number of hours spouses spend at work or the degree of flexibility of a particular occupation, has also accounted for the way couples divide family work (Coverman, 1985; Presser, 1994). These time- availability considerations do, indeed, consider questions of rational negotiations and immediate practicality around housework division such that whoever has more time is supposed to perform the task or do more than the other. Likewise, Household labour allocation has also been attributed to spouses' sex role attitudes (Ferree, 1990; Shelton and John, 1996; West \& Zimmerman, 1987). According to the gender ideology perspective, housework performance by women and/or men as well as the type and amount of it is but a symbolic enactment of the gender roles they are socialized to conform to. Although the above three leading theoretical perspectives provide important information on how some particular factors are associated with the division of domestic labour, they conceptualize the latter as an outcome rather than an inter-personal process of continuous negotiations over family labour.

\section{Thompson's distributive justice framework}

The distributive justice framework was initially proposed by Major (1987) to examine perceptions of fairness at the workplace, and how these 
differ from men to women. Major's approach is refined by Thompson (1991) to be applied to household labour division in order to explain women's sense of fairness about their share through three main factors- valued outcomes, justifications and comparison referents- formerly proposed by Major (1987).The first component concerns what people expect from close relationships and the symbolic meaning they give to a particular task. Thompson (1991) explains that:

Most women experience family tasks as essential work for the people they love, they enjoy ministering to the needs of their loved ones and keeping the family going, even if they do not enjoy the tasks themselves.

Thompson, 1991: 184

Therefore, as long as enjoyment and/ or psychological rewards are derived from taking care of one's family members, women may not necessarily seek an equal share of domestic tasks with their spouses. They are even more likely to be motivated to perform more. Women may also use some comparison referents to judge the fairness of their load of housework. They might often compare their workload with that of their own peers (Major, 1993) or their spouses' workload with that of their friends and relatives' husbands, some of whom contribute very little, and find themselves comparatively blessed no matter how large is the bulk of household responsibilities on their shoulders. Comparison might also be with prior experience and expectations (Gager, 1998). The justifications women use to evaluate the fairness of household labour allocation constitutes the third component of Thompson's (1991) distributive justice framework. Several examples of gender-linked justifications can sometimes be provided by women to account for their husbands' lower or non-existing contribution in domestic tasks. These justifications are further supported by societal norms promoting gender-segregated housework tasks allocation which, from the view of functionalist theories, is unproblematic as it maintains the natural social order. This perspective cannot, however, be applied to today's gender realities in a society of dual-employed couples. The aim of this paper is to examine the issues related to housework divisionin dual-work Moroccan families. The main objective is to determine the factors behind women's choice to perform more or all of the household labour and the role of valued outcomes and justifications in determining such a deliberate choice.

\section{Methodology}

The study is based on fieldwork research and is grounded in face-toface semi- structured interviews conducted with 30 Moroccan married female teachers. Indeed, the fact of limiting the participants to a specific professional group will help to decrease the variation in the other 
occupational characteristics such as the salary, the working load, the time off, the travel opportunities and others. Another reason for focusing on female teachers is motivated by the social belief that the job is ideal for married women as they have more free time, their schedule is more flexible and they are more available at home. The focus is purposefully on those with two or more dependent school-aged children in order to reflect similar types of household labour demands, responsibilities and socio-emotional dynamics. Moreover, the current study focuses on women who are primarily responsible for the performance of domestic tasks; i.e. those who do not rely on the help of any relative or any fortnight waged domestic help. Such narrow criteria have indeed been established with an aim to control the possibility that variation in family type would account for variation in observed patterns of household labour division. Most research on the division of household labour among dual-earner couples has failed to do that, resulting in few representatives of each family type.

To recruit participants with the demographic characteristics stated earlier, a snowball sampling technique has been adopted. The researcher relied initially on some acquaintances, gathered information from them, and then asked them for assistance in identifying other women who would fit the selection criteria. Accordingly, the chain process of referral continued to grow until the desired sample size was obtained.

To ensure the scholarly value of the research, the participants were given a written consent form that included explanations of the purpose of the study, participants' role and rights, confidentiality of the data as well as other information regarding the researcher's expectations. Given the importance of qualitative interviewing in social sciences, particularly in providing a deeper understanding of social phenomena (Mason, 2002), a semi-structured interview guide has been designed so as gain a deeper insight into the issue and get more information from the respondents. Effort was also made not to monopolize the conversation and avoid biases while interacting with the participants while focusing on the issue.

The main instruments relied a work-experiences survey that aimed at collecting data on the characteristics of the participants' occupation. This included a set of questions in which the participants were asked to specify the reasons that have led them to choose teaching as a profession, describe the positive and negative aspects of their job, and the impact, if any, it has on their family life. The second instrument examined participants' housework arrangements. More specifically, questions concerned their negotiations of domestic tasks division, if any, with their husbands, the importance they give to cleanliness and household maintenance as well as the tasks they like performing and those they enjoy the least. The instruments also included a detailed-week description plan in which participants were asked to describe 
their full day out of work including the weekend. In addition to the core interview questions, other follow-up questions were asked for more clarification, examples, counterexamples or details, hence allowing access to in-depth knowledge about participants' usually taken-for-granted activities and/ or behavior. It is worth- noting that for the three instruments, a special attention was to make subjects at ease because it is believed that when participants are comfortable and trusting, they are more likely to relate richer stories and elaborate explanations.

The data collected were transcribed and critically reviewed. More precisely, answers to the core questions together with those of the follow-up focus questions were analyzed by classifying them in a way to compare, examine, conceptualize and categorize the arising concepts (Strauss \& Corbin, 1998). In so doing, some repeated ideas and elements became apparent, and specific concepts emerged. These were, in fact, capturing different explanations of the inequity of household labour division. The emerging concepts were then extracted, and grouped into larger pertinent theoretical themes. Eventually, a thematic analysis went on through a grounded theory approach that has not however generated a completely new theory. It has rather grounded the findings on an already existing analytical framework in social psychology, first proposed by Major (1987) to study perceptions of fairness in the paid labour, then elaborated by Thompson (1991) in order to examine the cognitive and social-psychological processes underlying the perceptions of fairness in relation to household labour division among couples.

\section{Results and Findings}

Research on household labour division report that women's acceptance of an inequitable housework division might suggest an acceptance of the social beliefs and expectations regarding the role of women inside their households and men in the paid labour market (Blair \& Lichter, 1991; Presser, 1994; Sanchez, 1994). It might also be suggestive of an embedded negotiation between spouses over inputs and outcomes (Ferree, 1991; Greenstein, 2000; Kamo, 1988), or of a rational allocation of tasks based on spouses' relative hours in their paid job (Coverman, 1985; Haddad, 1996). Although these perspectives have much been supported by the literature, the participants raised other important issues. Despite the small sample size, some shared beliefs, comparable priorities and similar values have been brought to light. Most importantly, the present study revealed that most women in the sample perform more domestic tasks than their husbands out of choice. In other words, different internal factors proved to go into women's choice to do so. These relate mainly to personality attributes, 
upbringing values and standards of cleanliness and household maintenance. Each factor is presented in details below.

\section{Personality attributes}

Different individuals have different and distinctive characteristics that are likely to influence one's behaviour, preferences and decisionmaking. With regard to household labour division, our concern in the present paper, particular personality attributes proved to influence women's own decision to be in charge of one or more domestic task. Nawal, for instance, though having four children and no permanent help at home, as is actually the case for all women in the sample, chooses to do everything herself. She qualifies herself as being a multi-task person.

Palhamdulilah, kajomkə nndir bəzzaf djalləћwaj3 fnafs Palwaqt. kajomkən li nkunkanysollommaৎən, mqabla lmakla fuq liafja Pawla lforran, mduwra lmakina DSSabun, wo kanћəDDor fotelefo:n mSa

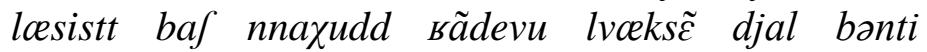
dotaltsnin $w$ matalan Pini Sla twimijjin Sandhum Tnafl Sam wlowlijjod djal sotsnin fle dovwa: razli kajbyi

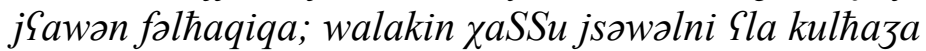
(kinder hadi? Ndir hadi bəSda wlahadi? Jnu ndir

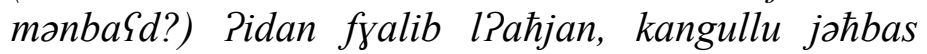
wonkammol Pana, bonnisba ldrari, huwa Sandu lxaTTər mSahum, kajsaSədhum folwazibat folwi:kand,

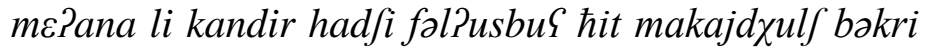
LDDar womajomkanf drari jobqaw jotsənnawh. ${ }^{38}$

...Thanks to God, I am able to do things at the same time, I can often be at the kitchen doing the dishes, checking the food on fire or in the oven, have the machine for the laundry going while being on the phone with the doctor's assistant to arrange a meeting for my three-year-old daughter's vaccine, and for example supervising my 12-year-old twins and 6-year-old son on homework as well". My husband offers to help a lot honestly, but he should ask me about the details of each task. (How should this be done? Should this be first? What should be done next?...etc). So in many occasions, I just ask him to stop and I just prefer to carry on. Concerning children, my husband has got a lot of patience with

${ }^{38}$ International Phonetic Alphabet (IPA)

For the full IPA chart, see: http://www.internationalphoneticassociation.org/content/ipa-chart 
the kids; he helps with homework at the weekend but it's me who takes charge of this on weekdays because he comes home late and the kids cannot wait until he comes then start homework.

Wafae, on the other hand, views a messy house as a reflection on her as a wife and a mother. She explained that she does not accept being negatively judged by visitors especially if someone comes in without calling ahead. Therefore, she tries her best to maintain order and organization and manages to keep her house in a state for entertaining amid all her other responsibilities. Wafae also confessed how fundamental it is for hospitality to have home-made almond-filled pastries to offer to her guests. In her words:

\section{Pataj wo dwazu huwwa bas kanrhbu bəDjaf}

Served together with mint tea, is a way to make your guests feel welcome.

Therefore, in order not to run short of pastries, she meets with her next-door neighbor once a month to prepare different assortments.

\section{Upbringing values}

Wassila, for example, stated that, with her three brothers and sister, she was brought up in a very clean and well- ordered house. Wassila claimed that she has never seen her parents' house in an untidy state; she added that when hosting guests, she started tidying the house, together with her mother and sister, once the guests left (doing the dishes, arranging the dining-room, vacuuming the carpet...), and that nothing is left for the following day. In her own household, she therefore unquestionably follows the same path; Wassila cites the following simple example:

...kajamkan Matalan nkun mtakja wyi

nfuf fiћaza fLarD, nnuD dikssasa

wənSawbha wla nrozzaSha labLaStha.

....for example, I can be lying on my bed and as

soon as I see something on the floor, I stand up

at once and go to arrange it.

Wassila is, for example, constantly at war with her husband over the debate of allowing their children to play in the living room. While she is totally against, her husband does not see a big deal with the fact of playing around the house. When children happen to bring their toys and playthings into the living room, she orders them to collect these as soon as they finish, and sometimes stops them before. Her husband, however, thinks it is nonsensical to tidy the room since the children would mess it up again especially at weekends and holidays, and always tries to convince her that it is just a temporary period. 


\section{Dajman kajgulli bi?annahu drari kajkbru wə yadintwəћfu} had llaћaDat.

He always tells me the children will grow up so fast and that I will miss these moments

Wassila clearly admits that this unrestful process makes her very exhausted but argues that she can do nothing about that since that is the way she has been brought up.

\section{Personal standards of cleanliness and order}

A clean and neat home is undoubtedly pleasing for both the residents and the people coming for visit. A clean and organized environment is likely to have a positive effect on people's well-being. In fact,some women do set high standards of order and cleanliness in their household than others, and, thus, choose to take the whole responsibility for the household chores than to delegate one or more to someone who will not do the tasks in accordance with their high standards. Madiha, for example, indicated that her husband used to volunteer to do some of the chores, but she usually does not accept his help. In the interview, Madiha declared that her husband has often suggested hiring a fortnight domestic helper, but she has always rejected that possibility, though she admits that her present situation is stressing and very tiring. She stated that she prefers to spend all day doing housework than to delegate her household tasks to someone who will not perform them properly or correctly, i.e. according to her own standards of quality, order or cleanliness. Domestic servants, she said, just move everything out of sight or simply move the mess around and pack things into cupboards; her husband and her ten- year-old daughter, she said, have the same tidying techniques whenever they are asked to help. In fact, some women like things to be done in a certain way known only to them. As Madiha said:

$$
\begin{aligned}
& \text { Sandi Tariqti PalzaSSa worazli mayajaSraff } \\
& \text { niha?ijjon jdir dakfi binafs TTariqa } \\
& \text { I have my own proper method; my husband will } \\
& \text { definitely not know how to do that in the same } \\
& \text { way. }
\end{aligned}
$$

With respect to cooking, Madiha adds:

....Pana Sandi razal kajTajab Slajan kulfi wəkajৎazbu jTajjab, kajon fimarat huwa li kajTajjab falwikand wla fas makankunf Pana fDDar, walakin majamkanf lik ttSawri rrwina falkuzina monbaSd (TTbajaS waLaSuS falhajT)

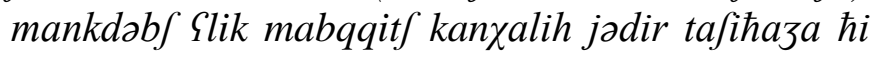
tkanaSraf ?af kajtsannani mənbaSd dak layda Pawlla lasfa. 
...My husband knows how to cook nearly everything and he quite loves that, he used to live alone here in Casablanca before marriage; his parents live in Oujda. I guess that helped him a lot. So, it happens that he cooks lunch or dinner at weekends or when I am not home, but you cannot imagine the mess in the kitchen after he finishes (stains and sauce everywhere). To tell you the truth I no longer let him do anything now because I know what I would expect in the kitchen after that meal.

The above example provided by the participant above justifies her choice to take the responsibility for cooking since she believes that her husband, despite his skill, will not do it the way she would.

Another example of participants whose husbands are willing to contribute to family tasks but who choose not to share is Nezha. The latter described herself as being too perfectionist and obsessive about the state of her home.

Pana mwasawssa

I am obsessed with order

Because of her obsessive-compulsive personality, Nezha always seeks a certain level of perfection and exactness in all housework and childcare chores. For instance, the table needs to be properly and aesthetically set for breakfast, lunch and dinner; clothes need to be symmetrically aligned in the wardrobes and shoes meticulously lined up in closets and taken off before entering the home as she considers them to be just for the outdoors. In doing this, things are generally arranged a certain number of times before Nezha finally gets satisfied of the result. She went on saying that if something is out of place, she stresses very quickly:

...DikssaSa kajDarrni raSi Pila kanat lhaza mafi fmakanha

...If something is out of place, I feel as if I have a headache.

While justifying her choice to perform everything around the house, Nezha said that she would readily and happily share the household chores equally with her husband if the latter would perform them to her own standards of quality, which her husband describes as too excessive, but which she cannot lower.

\section{Task Competence}

Competence in a particular task, through education, training, experience or innate abilities, usually affects people's performance of it. Culinary competence, for instance, implies a knowledge of how and what to prepare as well as an interest in that activity. It might also involve an ability 
to perform multiple meal preparation activities in parallel. Women have long been associated with being in the kitchen; thus, everyday cooking has culturally been, and still seems to be, women's responsibility. Men do cook sometimes, but often get credit if they do and are praised for their efforts more than women. Most female participants in this study claimed they are more qualified to take charge of cooking since they perform it, in most cases, better than their husbands. To competence, two of our participants added the role of nutritional personal health knowledge in the quality of their food selection and preparation of meals.

Furthermore, because fathers have become, by and large, more involved in childcare activities, some women enjoy seeing their husbands spending time with their children. Wassila, for instance, eagerly takes the responsibility for all housework tasks as long as her husband takes care of the children. In her words:

...Pal?ab djalhum kajৎəzbu jaļab mSahum, jəlawnu, jənaqzu huwa mən ?ənnawə? li kiћmaq

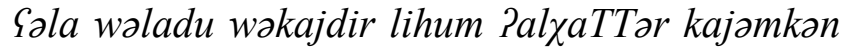
nobqa fDDar ?ana naqdi foyul wo huwa kajxarrozhum bədarrazaat ?aw Trs:tineT Pila Paxirih......liDarazat maSamru maqtarəћ nұarzu yir? ana wijjah bla bihum wohadfi ?ana kajkfini bћajat makanTLabs monnu ?aktar josSadni wala jihaza.

...Their father likes playing with them, they can colour, jump together and so on; sometimes, he takes them out with their bicycles or scooters while I stay in; he really adores his children, he has never suggested that we go out (he and I) alone without the kids; this I think is enough for me, so I don't ask him to do more, for example helping me with other routine tasks concerning the kids, the house or something like that.

\section{Specific Task Preference}

Cooking, for instance, is known to be one of the most enjoyable hobbies for many people. This is the case of Hayat who is very keen on cooking. She considers the latter to be her most preferred free-time activity and escape as it eases her whenever she does not feel well. Hayat particularly enjoys combining flavors, trying new ingredients and preparing different sauces:

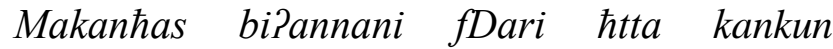

falmaTbax; fas kankun mqalqa, kanəmfi nSawəb 


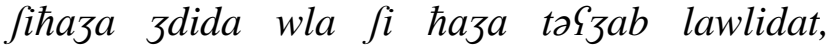
məndajman kan kaj€zabni nTTijəb, mni kanSandi Tnas lGam, bdit kanfri ktuba djal kuzina wkanhawal nhaDDar Puklat mutanawi a lDarna wkant kanafrah bəzzaf mni kandakfi kajSDaq wkaj\}zəbhum, liDarazat Pannani kunt gaS baya ntzbbaS had Palmajdan lawla Panna

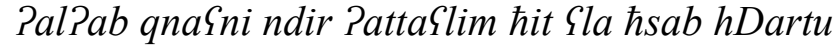
munasib li Palmar?a.

I do not feel at home unless I am in the kitchen; whenever I feel upset, I start preparing a new or exotic dish or something the kids love. I have always enjoyed cooking, when I was 12, I started to buy cookbooks and tried to produce different dishes for my family and I got very happy when I succeeded and happier when everybody loved what I prepared. I even wanted to follow a career in cooking but my father convinced me to do teaching, which, he said, is a practical and stable job for women.

$W a r d a$, on the other hand, explained that food shopping is one of her favorite things ever since she was young; she put:

...kanəm/i fwasTT liusbus baf manlqaf zzћam dəlwi:kand, kanfəDDaL nəm/i buћditi, kanm/i mhənja lidalik Samri mahtazit fi musaSada, wəmni kənt mazal fDarna wana kaj€zabni nəm/i natqadda.

...I especially go on weekdays to avoid the crowd of the weekend, and I prefer going alone, it is something that I enjoy doing so I have never asked for help.

Therefore, how much a person likes or dislikes a particular housework task affects his or her proportion of it since he or she will not mind taking the responsibility for that task.

\section{Husband's lack of self-initiative}

Some of the women interviewed acknowledged that their husbands helped in the performance of quite many domestic tasks but at the same time voiced their dissatisfaction in relation to their husbands' lack of initiative to do a particular task without being asked to. Specifically, though they are sometimes helped by their husbands, these women explained that were the ones who initiated, managed and organized all housework and childcare chores including those done by their husbands. Even taking out the garbage, 
Rajae confessed, is a task which is sometimes initially carried out by the woman herself. Though Rajae's husband is said to be in charge of taking the garbage out, she claims she is the one who arranges the latter, puts it in plastic bags, ties the bags tight and puts them next to the door. Her husband then has just to take it outdoors at her request. One might conclude then that despite some contribution from husbands, the whole responsibility for household labour falls primarily on women's shoulders.

\section{Importance of husband's providership}

Because society generally places higher importance on men's job and expect men to be the family breadwinner or at least to earn more than their wives, we have found that women in the current sample, particularly those whose husbands are in managerial or professional occupations, prioritize their husbands' financial and career goals over their own. One participant, Fadoua, openly admitted that her husband's business career needs to come first; for that, she willingly accepts to be in charge of everything concerning the house and the children.

...Pana mostaSədda ndi rkulfi yirjoxdam huwa ?ana

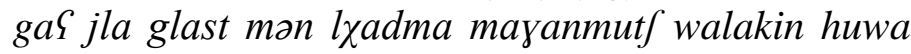

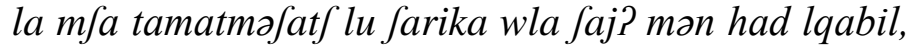
yanomfiw fiha kamlin.

...I am ready to do everything around the house, he just needs to work. If ever I stop work and stay home, I won't die; whereas if his business is not going well or something like that, we'll get in a real trouble.

\section{Attention and Care for the Spouse}

In an attempt to care for their husbands, some women choose to be in charge of all the household chores and do not complain about any unfairness regarding tasks allocation. Nawal, who qualified herself as a multi-tasks person, as emphasized above, has also admitted that among the reasons which make her do everything by herself is a personal effort to care for her husband, make him glad to come home instead of immersing himself in outside activities at the expense of family time. For that, Nawal is ready to cook the things he likes, keeps the house clean and well-arranged, takes time to listen to him when he gets back home in the evening...etc. In her words:

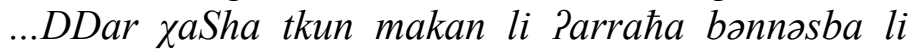
Parrazul fin jonsa mafakil PalSamal.... razli kajsijjor

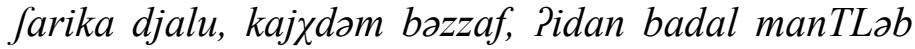

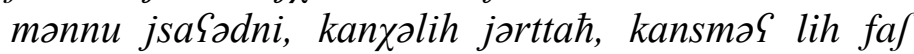

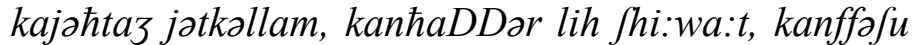
fwijjaf...rrazal kimma galu nas zman, Pilamalqas 
Porraћa $w$ alPihtimam fəDDar, rajqallab Slihum fmakan Paxar, rzal hakka dajrin, wmafi Slaqallat loSjalat li kajtssonaw yi had lfurSSa.

...The household should be a place where men can relax and forget the problems of work, she said. -My husband runs his own company, he really works hard, so instead of asking him to help; I rather listen to him whenever he needs talking, I prepare the dishes he likes, I am spoiling him ...laughs. If a man doesn't feel enough attention and rest at home from his wife, he will seek that elsewhere; this is how men are, and there are many women whose job is to make designs on married men and just wait for such an opportunity.

In this quotation, it is clear that Nawal considers herself a wise woman who believes that a successful marriage is the foundation of a healthy and happy family. She is entirely convinced of the need to meet her husband's needs and keep her house going by creating a peaceful and wellmanaged environment.

Wafae, on the other hand, claimed she does everything around the house because her husband, a cab driver, has a very tiring job and tends to spend all the day out:

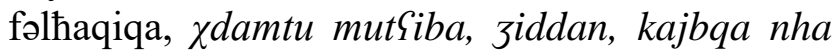
rkullu kajSug fafams, Pidan Sadi ?annahu fa jzi

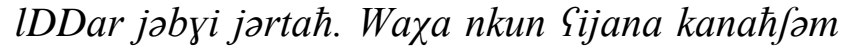
nTLab таппи Jiћaza.

His job is very tiring; he keeps driving all the day, so it's quite normal to take rest when he comes home. Even when I get tired, I don't dare ask him for anything.

\section{Lack of alternative options}

Apart from those female participants who chose not to share family tasks with their husbands because of different reasons pointed to above, the study also showed that some women do expect a shared responsibility. These women continuously ask their spouses to help in particular tasks. However, because their requests are generally not implemented, they just end up pursuing the task themselves and give up seeking assistance from the husband. This wife demand/ husband withdrawal pattern, as Kluwer et.al (1997) name it, make women who are relationship-oriented carry the task themselves to avoid conflict and build a stress-free marital relationship. Malika, for instance, claimed that when she asks for help from her husband, 
though just occasionally, if she is not well, sick or when the load is too heavy, the latter usually promises he would do the requested task once the program on television finishes or once he takes some rest but ends up doing nothing. Malika also adds that because he is a slow kind of a person who grew up in a very slow-paced environment as she claimed, she cannot even rely on him in driving the kids to school because she knows that they will never be on time to classes. The latter then wakes up at around seven o'clock having only the task of preparing himself for work. She therefore finds herself with no alternative but performing everything herself.

...majamkanf nxxalli lhaza hakkak, faf kajkunu

lommaSən mSarmin foloevobo: kanəbqa tanəbqa wanaysalhum ?ana fhaldima.

...I can't leave the task undone, when dishes are piled up in the sink, I end up doing them myself as is always the case.

\section{Effect of distributive justice}

While economic, rational and social theories ${ }^{39}$ are important in examining household labour division, they have provided insufficient explanations of the imbalance of tasks allocation among dual- income working couples. Therefore, because the patterns explained by these theories remain puzzling, support has also been shown for the distributive justice framework. In fact, based on the interviews with the participants, several factors have been referred to. These factors relate mainly to the desirability of a particular outcome value or to personal justifications of a particular behavior with regard to household labour.

The analysis of the participants' perceptions of their household labour division revealed that some tasks or relational outcomes are quite valued. These outcome values linked to a particular family task or to an effort to maintain good family or marital relationships affect the way spouses judge the allocation of chores in the household. In other words, in spite of working for pay, women from this sample are seen as the primary managers of the household work who do much more household labour than their husbands and yet, do not complain about their situation.This might be explained by the fact that many enjoy the positive results of the tasks they do at home and that concern both the house and family members. Although housework chores are not rewarding in themselves, many, nonetheless, do embody certain aspects of care. Gains might be simply felt from cooking a dish everyone likes or cleaning and arranging the house for one's family members. Also, in line with Robinson and Melissa's (1998) study on

\footnotetext{
${ }^{39}$ Relative resources theory, time availability theory and gender-role ideology
} 
women's attitudes toward housework, significant feelings of enjoyment have been found to be associated with having a neat home. Feelings of reward might also be achieved when receiving a compliment or a simple nice word from the spouse for any effort on the wife's part. These examples show how the valued outcomes of a particular domestic task allow women to judge an apparent unequal situation as being acceptable as well as fair. Moreover, because femininity is commonly thought to emphasize concern and care for others, it is easily expected that women would be more likely than men to derive satisfaction and enjoyment from any family-related activity and less likely to perceive the latter as a burden. Yet, they are likely to be susceptible to not getting credit for some domestic tasks such as cooking, especially from the husband. In sum, empathy proved to be more important than sharing for our female participants.

In addition, participants justified their greater role in household labour by pointing out to some factors that generally concern women more than men such as competence of the spouse, usually the wife, in performing or managing a particular family task, awareness of how much needs to be done and how often this needs to be performed, or a special ability to carry out several chores simultaneously. Besides, though some husbands who volunteered to contribute, some women preferred to perform the tasks according to their own quality standards, hence the lower reported share, for example, of men's involvement. Other justifications of the wives' willingness to perform more can be an attempt to avoid any possibility of conflict or disagreement over tasks division in the household that may arise due to different reasons. One of these reasons is often husbands' lack of initiative to perform a particular household chore without being prompted or reminded or, more, refusal on the husband's part to take part in domestic labour at all. Surprisingly, the acceptance of such an inequitable situation has been perceived as a display of wisdom on the part of wives in that they seek to maintain a healthy, peaceful and respectful marital life free of conflicts. This conflict avoidance is mainly found in traditional couples where women are inclined to avoid the negative consequences of conflict over domestic tasks despite their feelings of frustration (Hochschild, 1989). Husbands' hours at the paid work, job demandingness or role in family provision further served to justify their lesser participation in domestic chores. In other words, because the perceived social standing of a particular occupation is likely to affect the social class background, jobs held by men are valued differently depending on the social status each professional position has. Particularly, the assumption that the husband's job is more important than his wife's still persists today especially if the latter is pursuing an engaging or sociallyesteemed occupation. This has been repeatedly replicated in the televised world; the portrayal of men's occupational roles has often stereotypically 
shown men pursuing careers of high status. Therefore, many wives put their husband's career over their own and excuse them from not participating in family tasks because they claim they work, in general, longer hours and feel that they cannot work all day at their paid job only to arrive home and be expected to contribute in housework tasks as well.

Many of these justifications come, therefore, to be in line with the functionalist perspective, which suggests that segregated gender roles are beneficial for promoting social stability and smooth running of the family. However, such subjective justifications do, in fact, limit women's will to challenge any unequal division of household labour and promote the gendered unequal household arrangements.

\section{Conclusion}

The purpose of this study was to investigate the division of family tasks among a sample of thirty Moroccan working couples with a particular focus on women's larger share. Drawing on data from qualitative in-depth interviews with the wives, our results provide strong support for the significance of the distributive justice framework in explaining the extent to which household labour division, usually unequal, is perceived as being fair by dual-work couples. Consistent with other previous studies on the issue, it was found that an uneven distribution of housework did not necessarily invoke a sense of unfairness; participants were indeed influenced by some factors they perceive as justifiable and legitimate or by other important positive outcomes they have been socialized to value while or after performing domestic tasks.

Hence, because family life and marital relationships are quite complex, it has often been difficult to draw definite accounts of the allocation of household labour tasks among dual-earner couples. The current study, however, widens the research on the topic by being more inclusive of other emerging personal assessments of household labour division that are also at play in addition to pragmatic or structural factors and gender ideologies. Nevertheless, it would be beneficial for these aspects to be explored in future research to gain a greater understanding of how dualearner couples manage their family labour.

\section{References:}

1. Belarbi, Aicha. (1991). Le Salaire de Madame. Casablanca: Editions le Fennec.

2. Berk, S.F. (1985). The gender Factory: The Appointment of work in American Households. New York: Plenum. 
3. Bianchi, S. M, Milkie, M. A., Sayer, L.C., \& Robinson, J.P. (2000). Is anyone doing the housework? Trends in the gender division of household labour. Social Forces, 79? 191-228.

4. Blair, S. \& Lichter, D. (1991). Measuring the division of household labour: gender segregation of housework among American couples, Journal of Family Issues, 12, pp. 91-113.

5. Blood, R. O., \& Wolfe, D. M. (1960). Husbands and wives: The dynamics of married life. New York: Free Press.

6. Brines, J. (1994). Economic dependency, gender, and the division of labour at home. American Journal of Sociology, 100, pp. 652-688.

7. Coverman, S. (1985). Explaining husbands' participation in domestic labour. The Sociological Quarterly, 26: 81-97.

8. Ferree, M. M. (1990). Beyond separate spheres: Feminism and family research. Journal of Marriage and the Family, 52, 866-884.

9. (1991). The gender division of labor in two-earner marriages. Journal of Family Issues, 12, 158-180.

10. Gager, C. T. (1998). The role of valued outcomes, justifications, and comparison referents in perceptions of fairness among dual-earner couples. Journal of Family Issues, 19, 622-648.

11. Greenstein, T. N. (2000). Economic dependence, gender and the division of labour in the home: A replication and extension. Journal of Marriage and the Family, 62, 2: 322-335.

12. Haddad, A. (1996). The sexual division of household labour: Pragmatic Strategies or patriarchal dynalics?: An analysis of two case studies. North York: York University.

13. HCP. (2016). La Femme Marocaine en Chiffres: Tendances d'évolution des caractéristiques démographiques et socioprofessionnelles. Rabat : Haut Commissariat au Plan.

14. Hochschild, A. R. (1989). The second shift. NewYork, NY: Avon Books

15. Kamo, Y. (1988). Determinants of household division of labor. Journal of Family Issues, 9, 177-200.

16. Kluwer, E. S., Heesink, J.A.M., Van de Vliert, E. (1997). The marital dynamics of conflict over the division of labor. Journal of Marriage and the Family, 59, 635-653.

17. Major, B. (1987). Gender, justice and the psychology of entitlement. In P. Shaver and C. Hendrick (Eds.), Sex and gender (pp. 124-128). Newbury Park, CA: Sage.

18. Major, B. (1993). Gender, Entitlement, and the Distribution of Family labor. Journal of Social Issues, 49 (3), p. 141-159.

19. Mason, J. (2002). Qualitative Researching. London: Sage. 
20. Presser, H. B. (1994). Employment schedules among dual-earner spouses and the division of household labour by gender. American Sociological Review, 59, 348-364.

21. Robinson, J.P, and Melissa, M.A. (1998). Back to the basics: Trends and role determinants of women's attitudes towards housework, Journal of Marriage and the family, 60, 205-218.

22. Sanchez, L. (1994). Gender, labor allocations, and the psychology of entitlement within the home. Social Forces, 73, 533-553.

23. Shelton, B. A., \& John, D. (1996). The division of household labour. Annual Review of Sociology, 22, 299-322.

24. Strauss, A., \& Corbin, J. (1998). Basics of qualitative research: Techniques and procedures for developing grounded theory. Thousand Oaks, CA: Sage Publications.

25. Thompson, L. (1991). Family work: women's sense of Fairness. Journal of Family Issues, 12: 181- 196.

26. West, C., Zimmerman, D. (1987). Doing gender. Gender Society, 1: $125-51$. 